\title{
Congenital Hypomyelinating Neuropathy with Lethal Conduction Failure in Mice Carrying the Egr2 I268N Mutation
}

\author{
Robert H. Baloh, ${ }^{1,3}$ Amy Strickland, ${ }^{2}$ Elizabeth Ryu, ${ }^{2}$ Nam Le, ${ }^{2}$ Timothy Fahrner, ${ }^{2}$ Mao Yang, ${ }^{2}$ Rakesh Nagarajan, ${ }^{2}$ and \\ Jeffrey Milbrandt ${ }^{1,2,3}$ \\ Departments of ${ }^{1}$ Neurology and ${ }^{2}$ Pathology, and ${ }^{3}$ Hope Center for Neurological Diseases, Washington University School of Medicine, St. Louis, Missouri \\ 63110
}

\begin{abstract}
Mouse models of human disease are helpful for understanding the pathogenesis of the disorder and ultimately for testing potential therapeutic agents. Here, we describe the engineering and characterization of a mouse carrying the I268N mutation in Egr2, observed in patients with recessively inherited Charcot-Marie-Tooth (CMT) disease type 4E, which is predicted to alter the ability of Egr2 to interact with the $\mathrm{Nab}$ transcriptional coregulatory proteins. Mice homozygous for $E g r 2^{I 268 N}$ develop a congenital hypomyelinating neuropathy similar to their human counterparts. Egr $2^{I 268 N}$ is expressed at normal levels in developing nerve but is unable to interact with Nab proteins or to properly activate transcription of target genes critical for proper peripheral myelin development. Interestingly, Egr $2^{I 268 \mathrm{~N} / 2268 \mathrm{~N}}$ mutant mice maintain normal weight and have only mild tremor until 2 weeks after birth, at which point they rapidly develop worsening weakness and uniformly die within several days. Nerve electrophysiology revealed conduction block, and neuromuscular junctions showed marked terminal sprouting similar to that seen in animals with pharmacologically induced blockade of action potentials or neuromuscular transmission. These studies describe a unique animal model of CMT, whereby weakness is due to conduction block or neuromuscular junction failure rather than secondary axon loss and demonstrate that the Egr2-Nab complex is critical for proper peripheral nerve myelination.
\end{abstract}

Key words: myelin; peripheral nerve; axon; neuromuscular junction; nerve; neuropathy

\section{Introduction}

Charcot-Marie-Tooth disease (CMT) is a common inherited disorder of peripheral nerves characterized by progressive sensory loss and weakness beginning in the feet and legs, and later progressing to the hands (Charcot and Marie, 1886; Tooth, 1886). Remarkable progress has been made in recent years identifying many gene defects that can lead to this phenotype (Suter and Scherer, 2003; Shy, 2004; Nicholson, 2006). Based on nerve electrophysiology, most patients with CMT can be divided into two major forms. CMT type 1 is characterized by median nerve conduction velocity $<38 \mathrm{~m} / \mathrm{s}$, and genes mutated in this type are largely involved in the development or maintenance of myelinating Schwann cells (Pareyson et al., 2006). CMT type 2 shows

Received May 13, 2008; revised Dec. 29, 2008; accepted Jan. 11, 2009.

This work was supported by National Institutes of Health (NIH) Neuroscience Blueprint Core Grant NS057105 to Washington University, the Hope Center for Neurological Disorders, NIH Grants NS040745 (J.M.), 5-T32-DA07261 (E.R.), and 1K08NS055980 (R.H.B.), and the Muscular Dystrophy Association and Children's Discovery Institute (R.H.B.). R.H.B. holds a Career Award for Medical Scientists from the Burroughs Wellcome Fund. We thank Tatiana Gorodinsky, Nina Panchenko, Robert Schmidt, Karen Green, and Amber Neilson for technical assistance, and members of the Milbrandt and Baloh laboratories for helpful discussions and feedback on this manuscript.

Correspondence should be addressed to either of the following: Dr. Robert H. Baloh, Department of Neurology, Washington University School of Medicine, P.0. Box 8111, 660 South Euclid Avenue, St. Louis, M0 63110, E-mail: rbaloh@wustl.edu; or Dr. Jeffrey Milbrandt, Department of Pathology, Washington University School of Medicine, P.0. Box 8118, 660 South Euclid Avenue, St. Louis, M0 63110, E-mail: jeff@pathology.wustl.edu.

D0I:10.1523/JNEUROSCI.2168-08.2009

Copyright $\odot 2009$ Society for Neuroscience $\quad$ 0270-6474/09/292312-10\$15.00/0 preserved nerve conduction velocity with diminished compound motor action potentials suggesting axon loss without myelin dysfunction, and genes mutated in CMT type 2 likely define molecular pathways necessary for axonal stability (Züchner and Vance, 2006).

The proper formation of myelin by Schwann cells requires a precisely controlled genetic program coordinated by a series of transcription factors including SOX10, SCIP/Oct6, Egr2, and Nab1/Nab2 (Jessen and Mirsky, 2002; Svaren and Meijer, 2008). Loss of these transcription factors disrupts the myelination process, as does persistent overexpression (Ryu et al., 2007). The remarkable precision in transcriptional control necessary for proper myelination is evidenced by the fact that relatively small increases or decreases in the quantity of myelin proteins can lead to myelin dysfunction and disease. For example, loss of one copy of PMP22 leads to hereditary neuropathy with liability to pressure palsy (HNPP), whereas PMP22 duplication leads to CMT1A (Lupski, 1997).

Egr2 is absolutely required for proper peripheral nerve myelination and serves as a master regulatory transcription factor in both developmental and regenerative myelination (Topilko et al., 1994; Le et al., 2005a; Decker et al., 2006). Furthermore, dominant and recessive mutations in EGR2 have been identified in patients with CMT (denoted CMT1D and CMT4E) (Warner et al., 1998). Egr2 interacts with two transcriptional coregulatory 
proteins, Nab1 and Nab2, which are able to act as either coactivators or corepressors of Egr2 depending on the promoter context (Russo et al., 1995; Svaren et al., 1996; Sevetson et al., 2000). Importantly, Nab1/Nab2 double knock-out mice have severe hypomyelination and early lethality, providing evidence that $\mathrm{Nab}$ proteins are also critical for myelin development (Le et al., 2005b). Although null and hypomorphic Egr2 mouse mutants have been instrumental in defining its role in myelin development, they have been difficult to study as models of human CMT in large part due to early lethality.

To further delineate the role of Egr2-Nab interactions in myelin development, and develop an animal model of CMT4E, we generated mice expressing a point mutation found in human CMT patients in Egr2 (I268N) under control of the endogenous locus. In contrast to other Egr2 mouse models, Egr2 ${ }^{I 268 \mathrm{~N} / I 268 \mathrm{~N}}$ mice initially grow normally but develop rapidly progressive weakness 2 weeks after birth, and electrophysiology and terminal axonal sprouting implicate conduction block as the mechanism of weakness and death in these mice. This confirms that disability in inherited peripheral neuropathy can be due to abnormal action potential propagation or neuromuscular transmission, separable from secondary axonal degeneration.

\section{Materials and Methods}

Generation of Egr2-I268N knock-in mice. Egr2 ${ }^{I 268 N / I 268 N}$ mice were generated using a strategy identical to that previously described (Le et al., $2005 \mathrm{a}$ ), except that the I268N point mutation was engineered into the targeting construct (supplemental Fig. 1, available at www.jneurosci.org as supplemental material). Mouse embryonic stem (ES) cell colonies were placed under selection for neomycin resistance, and the resulting colonies screened by Southern blotting. Genomic DNA from positive ES clones was isolated, and the I268N mutation was confirmed by direct sequencing of a PCR product spanning the mutation site. ES cells were injected into C57BL6 blastocysts to derive chimeric mice, and mice carrying the Egr $2^{I 268 N}$ locus were back-crossed to C57BL6 mice for six generations before analysis. Egr $2^{I 268 N / I 268 N}$ mice became severely weak after postnatal day 14 (P14), and were given food and water at the floor of the cage and monitored daily for progression. Mice were killed if they were unable to right themselves, or had signs of labored breathing, which uniformly took place between P18 and P21.

Immunoblot analysis and coimmunoprecipitation. Sciatic nerve and HEK293T lysates were analyzed by immunoblotting using standard techniques. Nerves were collected in lysis buffer (50 mM Tris-HCl, pH 7.4, $150 \mathrm{~mm} \mathrm{NaCl}, 1 \%$ Triton X-100, complete protease inhibitor mixture (Roche) and sonicated. Primary antibodies used were rabbit anti-Flag (1:1000, Covance), mouse anti-Myc (1:1000, Abcam), mouse anti-HA (1:1000, Covance), and mouse anti-Nab2 (1:1000) (Abdulkadir et al., 2001). For coimmunoprecipitation experiments, HEK293T cells were transfected with the indicated expression plasmids using the Fugene transfection reagent (Roche). Two days after transfection, cells were collected in low-IP buffer from the nuclear complex Co-IP kit (Active Motif) prepared according to the manufacturer's instructions, and incubated with Protein G-agarose beads bound to either anti-Myc antibodies, or M2-anti-Flag agarose conjugated antibodies (Sigma). Immunoprecipitates were washed in Co-IP buffer, and then analyzed by SDS-PAGE and immunoblotting. Generation of expression plasmids for Flag and HA-tagged mouse Egr2, Flag-Egr2 ${ }^{\text {I268N }}$, myc-tagged mouse Nab2 was described previously (Svaren et al., 1996; Warner et al., 1999).

Histology and electron microscopy. Mice were killed and perfused with $1 \%$ paraformaldehyde $/ 2.4 \%$ glutaraldehyde in 100 mm cacodylate buffer, $\mathrm{pH} 7.4$, and sciatic nerves were dissected and postfixed for $16 \mathrm{~h}$ in the same buffer. Nerves were transferred to $100 \mathrm{~mm}$ cacodylate buffer, $\mathrm{pH}$ 7.4, and processed for plastic and electron microscopic sections. Nerve segments were dehydrated and embedded in epon-Araldite. Nerve sections $(1 \mu \mathrm{m})$ were stained with toluidine blue for light microscopy evaluation. For electron microscopy, thin sections were prepared and imaging was performed using a JEOL 1200 electron microscope. We calculated $g$ ratios by mathematical division of axonal diameter by fiber diameter, that is, axonal diameter/(axonal + myelinating sheath diameter). Axon counts were performed from electron micrographs of sciatic nerve preparations. Axons $>1 \mu \mathrm{m}$ were counted in 2 fields, and total axon counts were calculated as (\#axons/area $\times$ total area of the nerve). Skin was collected after perfusion of the mice with $4 \%$ paraformaldehyde, paraffin embedded, cut into $6 \mu \mathrm{m}$ sections, and stained with hematoxylin and eosin.

Immunohistochemistry and analysis of cranial nerve development. Fresh frozen sciatic nerves were embedded in OCT (Tissue-TEK), cut into 10 $\mu \mathrm{m}$ sections, and fixed for $15-20 \mathrm{~min}$ in $4 \%$ paraformaldehyde. Sections were cut at $6 \mu \mathrm{m}$ and antigen retrieval was performed in $0.01 \mathrm{~m}$ sodium citrate for $30 \mathrm{~min}$. Blocking was performed in PBS-BB (PBS with 1\% nonfat dry milk, $1 \%$ bovine albumin, and $0.2 \%$ Triton X-100) for $30 \mathrm{~min}$ at $25^{\circ} \mathrm{C}$. Nerves were incubated with mouse monoclonal BrdU (1:200, Roche), rabbit polyclonal Pou3f1 (1:1000, generous gift from J. Bermingham, McLaughlin Research Institute, Great Falls, MT) or rabbit polyclonal Ki67 (1:1000, Vector Laboratories) in blocking buffer at $4^{\circ} \mathrm{C}$ for 14-18 h. Before incubation with BrdU antibody nerve sections were treated with $4 \mathrm{~N} \mathrm{HCl}$ for $10 \mathrm{~min}$. Fluorescently labeled secondary antibodies (goat anti-mouse Cy3 for BrdU; goat anti-rabbit Cy3 for SCIP and $\mathrm{Ki67}$ ) were applied for $1.5 \mathrm{~h}$ at $25^{\circ} \mathrm{C}$ in PBS-BB. Neurofilament staining of embryonic day 10.5 (E15) mice was performed as previously described (Le et al., 2005b). Briefly, embryos were dissected, fixed in $4 \%$ paraformaldehyde at $4^{\circ} \mathrm{C}$ for $18 \mathrm{~h}$, quenched of endogenous peroxidase activity and blocked in PBS with $4 \%$ BSA and $1 \%$ Triton at $4^{\circ} \mathrm{C}$ for $\sim 18 \mathrm{~h}$. Neurofilament antibody (Developmental Studies Hybridoma Bank clone $2 \mathrm{H} 3,1: 50$ ) was incubated in blocking solution for $48 \mathrm{~h}$ at $4^{\circ} \mathrm{C}$. Goat anti-mouse HRP secondary was then incubated in at $4^{\circ} \mathrm{C}$ for $18 \mathrm{~h}$, with signal development by diaminobenzidine tetrahydrochloride (Sigma).

For teased nerve immunohistochemistry, P14 mice were killed and sciatic nerves removed and postfixed in $4 \%$ paraformaldehyde for $1 \mathrm{~h}$ at $4^{\circ} \mathrm{C}$. Teased nerves were dried and stored at $-20^{\circ} \mathrm{C}$, before staining were postfixed with acetone for $10 \mathrm{~m}$ at $-20^{\circ} \mathrm{C}$, then blocked in $5 \%$ fish skin gelatin/0.1\% Triton in PBS for $1 \mathrm{~h}$. Rabbit primary antibodies, were incubated in blocking buffer overnight, slides were washed with PBS + $0.1 \%$ Triton and incubated in secondary goat anti-mouse Cy3 antibody for $1 \mathrm{~h}$ at RT. For mouse antibodies the Vector MOM immunodetection kit was used (Vector Laboratories), with visualization via alexa-488 streptavidin. Rabbit polyclonal antibodies and dilutions used were: Kv1.1, 1:100 (Abcam); Nav1.6, 1:100 (Millipore); Kv1.2, 1:100 (Millipore); Pan Nav, 1:250 (Millipore). Mouse monoclonal to Caspr was used at 1:1000 (gift from Dr. Elior Peles, Weizmann Institute of Science, Rehovot, Israel).

$q R T-P C R$ analysis of myelin gene expression. Sciatic nerves were collected from P14 mice, placed in Trizol (Invitrogen), homogenized, and total RNA was generated according to the manufacturer's instructions. First strand RT libraries were produced from total RNA using MMLV reverse transcriptase (Invitrogen), and analyzed using intron-spanning gene-specific primers with $2 \times$ Sybr-Green qPCR mix (Clontech) on an ABI Taqman machine. Levels of GAPDH transcript were used for normalization.

Neuromuscular junction analysis. To visualize the presynaptic component of the neuromuscular junction (NMJ) we used Thyl-YFP16 mice, which express YFP in all spinal motor neurons (Feng et al., 2000). Egr2 $2^{I 268 N /+}$ mice were bred with Thyl-YFP/+ mice maintained on a C57BL6 background, and then Egr $2^{\text {I268N/+}}$ : Thyl-YFP/+ mice were bred to Egr $2^{I 268 N /+}$ mice. Mice were killed at P14 or P18, perfused with $4 \%$ paraformaldehyde, and the diaphragm or extensor digitorum longus (EDL) muscles were removed. Muscles were postfixed in $4 \%$ paraformaldehyde, stained with Alexa-594 $\alpha$-bungarotoxin (Invitrogen) for $30 \mathrm{~min}$ at room temperature, and whole mounted onto slides for imaging.

Nerve electrophysiology. Electrophysiology was performed on mice at postnatal day $18-20$. Mice were anesthetized with avertin, and placed on a heating pad. Subcutaneous platinum subdermal EEG electrodes $(0.4$ $\mathrm{mm}$ diameter, $12 \mathrm{~mm}$ length; Viasys) were used. Stimulating electrodes were placed just above the left ankle and the left sciatic notch for nerve stimulation. Recording electrodes were placed in the footpad. Evoked compound motor action potentials (CMAPs) were obtained using a Vi- 
king Quest electromyography machine (Nicolet) using supramaximal stimulation, and distance between the two sites of stimulating electrodes was used to calculate conduction velocity.

\section{Results}

Generation of an Egr2-I268N congenital hypomyelinating neuropathy mouse model

Myelination in Schwann cells is critically dependent on proper gene dosage, and overexpression of wild-type forms of genes such as MPZ and PMP-22 are themselves capable of producing a demyelination neuropathy in rodents (Sereda et al., 1996; Wrabetz et al., 2000). To maintain this precise stoichiometry we created a mouse model of inherited neuropathy with a point mutation in Egr2 using a knock-in approach to incorporate the I268N mutation into the endogenous mouse Egr2 genomic locus (supplemental Fig. 1, available at www.jneurosci.org as supplemental material). This leaves the entire locus intact, with only a small loxP scar present in the single intron, thereby maintaining all necessary control elements for proper Egr2 expression. Indeed protein lysates from wild-type and $E g r 2^{I 268 N / I 268 N}$ mice showed identical protein levels of Egr2 in P14 sciatic nerve (Fig. 1A).

\section{The Egr2-I268N mutant protein is unable to bind to the Nab2} transcriptional coregulator

Many neuropathy associated Egr2 mutants have alterations in the DNA-binding domain and act in a dominant negative manner to inhibit myelin gene expression, consistent with their dominant inheritance pattern (Nagarajan et al., 2001). However, Egr2I268N leads to recessive disease and is able to bind normally to an Egr2 consensus DNA sequence, indicating that it has a different mechanism than loss of DNA binding (Warner et al., 1999). The I268N mutation is located in the $\mathrm{R} 1$ domain, a region in Egr family members that interacts with Nab proteins (Russo et al., 1993), though this has not been demonstrated for Egr2. Therefore, we expressed tagged Egr2 or Egr2-I268N together with Nab2 in $293 \mathrm{~T}$ cells, and examined their ability to directly interact via coimmunoprecipitation. Wild-type Egr2 and Nab2 were coimmunoprecipitated regardless of whether the complex was pulled down with epitope-tagged Egr2, or Nab2 (Fig. $1 B, C$ ). In contrast, Egr 2 carrying the $\mathrm{I} 268 \mathrm{~N}$ mutation did not coimmunoprecipitate with $\mathrm{Nab} 2$, indicating that Egr2-I268N is physically unable to bind Nab2. This provides a molecular basis for the previous observation that Nab2 does not modulate transcription of an artificial promoter system with Egr2-I268N (Warner et al., 1999), and supports the idea that abnormalities present in $\mathrm{Egr}^{I 268 \mathrm{~N} / 2268 \mathrm{~N}}$ mice are due the inability of Egr2-I268N to interact with Nab proteins.

$E g r 2^{I 268 N}$ knock-in mice develop rapidly progressive weakness at P14 and die shortly before weaning

Normal peripheral myelination in mice begins at around $\mathrm{P} 1$ and is completed from P14-P30 (Hahn et al., 1987; Bermingham et al., 1996; Mirsky and Jessen, 1996). Egr $2^{I 268 N / I 268 N}$ mice weigh the same as their wild-type and heterozygous $\left(E g r 2^{I 268 N /+}\right)$ littermates through the first 2 weeks of life, in contrast to Egr2 null, Egr2 hypomorphic, and Nab1/Nab2 null mice which are runted from birth (Topilko et al., 1994; Le et al., 2005a,b). However, Egr $2^{\text {I268N/I268N }}$ mice rapidly lose weight after P14 and inevitably die by P21 (Fig. $2 A, B$ ). The decline in function is striking, with only mild slowness and gait abnormality present at P14, but rapid ascending weakness leading to complete hindlimb paralysis and death within 4-7 d (see supplemental Movies 1-3, available at www.jneurosci.org as supplemental material). On gross inspection,

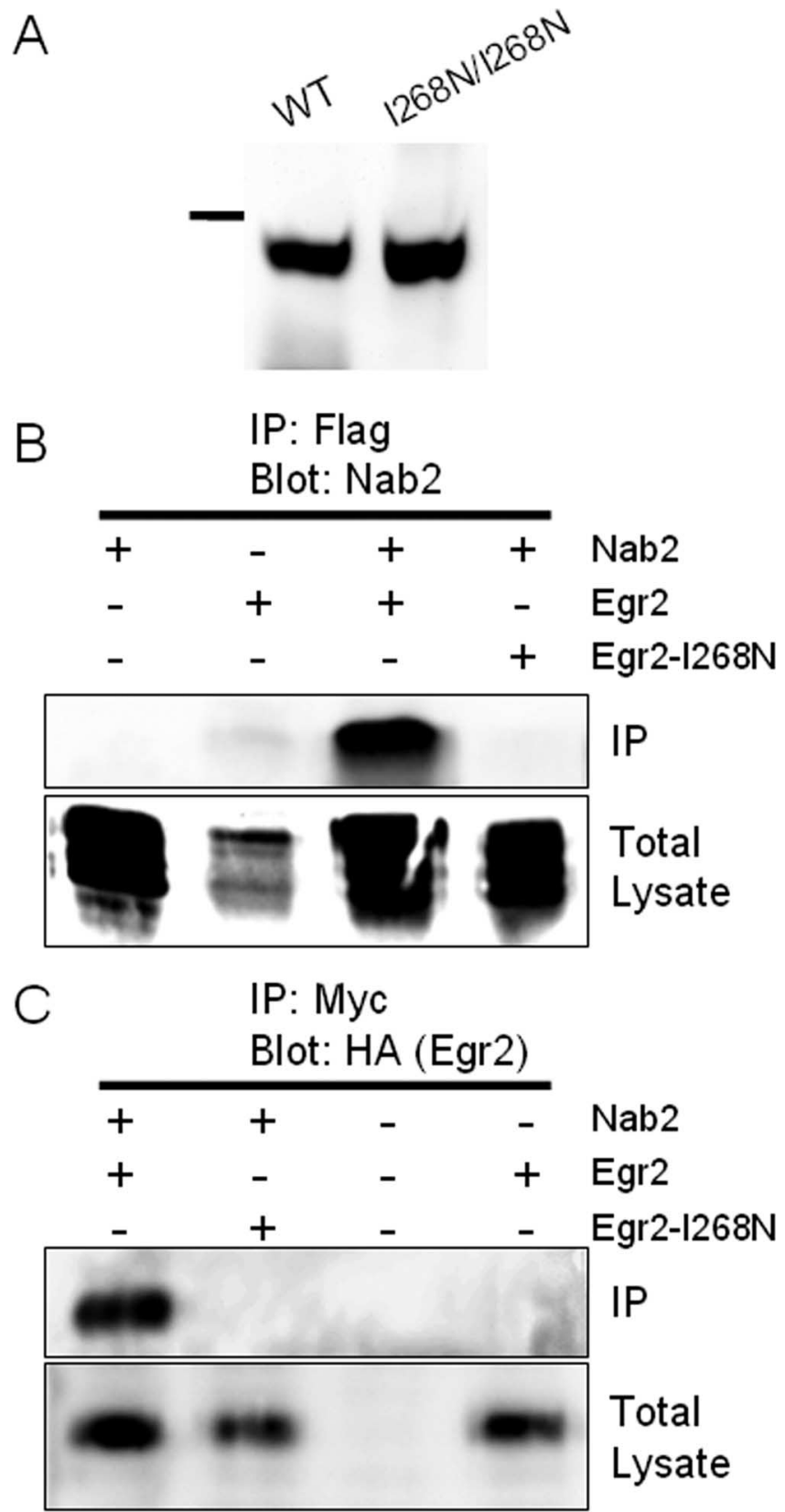

Figure 1. $\quad E g 2^{1268 N}$ is expressed at normal levels in developing nerve but is unable to interact with the Nab2 transcriptional coactivator. $\boldsymbol{A}$, Western blot of Egr2 in postnatal day 14 sciatic nerves. Equal levels of Egr2 protein are generated from both the wild-type (WT) and Egr2 ${ }^{1268 N / 268 \mathrm{~N}}$ locus. B, Egr2-1268N is unable to interact with Nab2. 293T cells were transfected with Nab2 alone or cotransfected with either Flag-tagged Egr2 (wild type or 1268N), as indicated. Samples were immunoprecipitated with anti-Flag antibody and immunoblotted with an anti-Nab2 antibody. C, Cells transfected with Myc-Nab2 and HA-tagged Egr2 (wild type or 1268N) were immunoprecipitated with anti-Myc antibody and immunoblotted with anti-HA antibody, again demonstrating that the Egr2-1268N mutant cannot physically interact with the Nab2 transcriptional coactivator.

the sciatic nerve appears translucent in Egr $2^{I 268 N / I 268 N}$ mice compared with wild type, indicating abnormal myelination (Fig. 2C,D).

Egr $2^{I 268 N / 1268 N}$ mice have hypomyelination, persistent Schwann cell proliferation, and decreased expression of genes associated with mature myelin

To examine in detail the myelin abnormality in $\operatorname{Egr}^{1268 \mathrm{~N} / \mathrm{I} 268 \mathrm{~N}}$ mice, we performed histological and electron microscopic anal- 

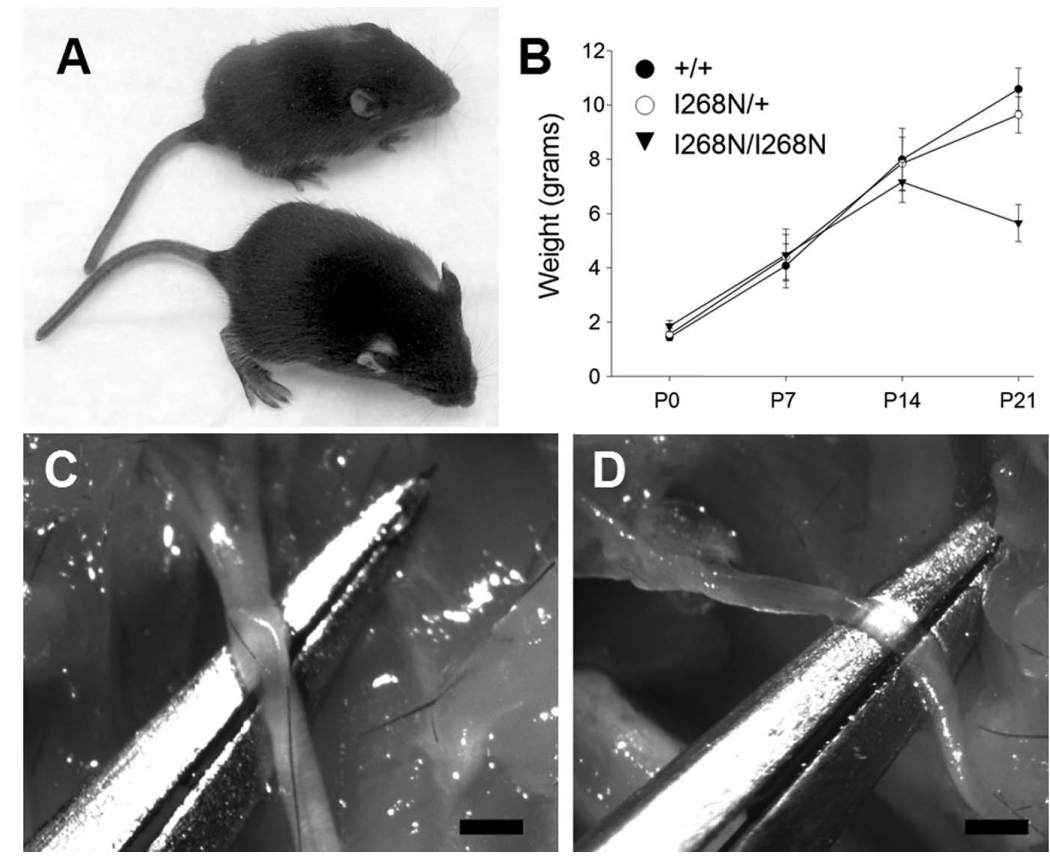

Figure 2. Egr2-I268N knock-in mice develop rapidly progressive weakness 2 weeks after birth and die shortly before weaning. A, Gross picture of Egr2 ${ }^{1268 \mathrm{~N} / 1268 \mathrm{~N}}$ (top) and wild-type littermates (bottom) at P14. Through 2 weeks of age, the mice are of similar size, and the Egr2 ${ }^{1268 \mathrm{~N} / 1268 \mathrm{~N}}$ mice show only a mild gait disturbance (see supplemental Movie 1, available at www.jneurosci.org as supplemental material). However, 4-7 d later, the Egr2 ${ }^{1268 \mathrm{~N} / 1268 \mathrm{~N}}$ mice have complete paralysis of the hind limbs, are no longer able to effectively nurse, and begin to lose weight. $\boldsymbol{B}$, Weight of wild-type $(+/+)$, heterozygous $\left(\right.$ Egr $\left.2^{1268 \mathrm{~N} /+}\right)$, and homozygous $\left(\right.$ Egr2 $\left.^{1268 N / 1268 N}\right)$ mice showing that Egr2 $2^{1268 N / 1268 N}$ mice rapidly lose weight between P14 and P21. No Egr2 ${ }^{1268 N / 1268 N}$ mice survived past P21. C, D, Gross pictures of P14 sciatic nerves from wild-type $(\boldsymbol{C})$ and Egr $^{1268 N / 1268 N}(\boldsymbol{D})$ mice. The sciatic nerve is transparent, consistent with hypomyelination in Egr2 $2^{1268 \mathrm{~N} / 1268 \mathrm{~N}}$ mice. Scale bar, $1 \mathrm{~mm}$.

ysis of the sciatic nerve at P14. Toluidine blue-stained plastic sections showed decreased numbers of myelinating profiles in Egr ${ }^{2268 N / / 268 N}$ nerves compared with wild type (Fig. $3 A, B$ ). Electron microscopy revealed that there were frequent large caliber axons without any myelin and that when present myelin sheaths were abnormally thin (Fig. 3D,F). Additionally, Schwann cell nuclei frequently appeared irregularly shaped. No onion-bulb formations nor myelin debris were present, indicating that no demyelination or remyelination had taken place by P14. Analysis of dorsal and ventral nerve roots showed that the abnormal myelination was present equally in sensory and motor nerves (supplemental Fig. 2, available at www.jneurosci.org as supplemental material).

To further characterize the abnormality in myelin development in Egr2 $2^{1268 N / I 268 N}$ mice, we performed immunohistochemistry on P14 sciatic nerves for markers of Schwann cell differentiation. Immunostaining for Pou3f1/Oct6/SCIP, a transcription factor important in the promyelinating phase of Schwann cell development, showed increased numbers of Pou $3 \mathrm{f} 1$ positive cells in $\mathrm{Egr}^{1268 N / I 268 N}$ nerves compared with wild type (Fig. 4A,B). Furthermore, more dividing nuclei were present in P14 sciatic nerves from $\mathrm{Egr2}^{1268 \mathrm{~N} / 1268 \mathrm{~N}}$ mice compared with wild type, as visualized by Ki67 immunostaining (Fig. 4B, C). These findings indicate that many Schwann cells in Egr2 $2^{I 268 N / I 268 N}$ mice are unable to progress beyond the promyelinating phase and continue to proliferate, similar to that seen in Egr2 hypomorphic and Nab1/2 null mice (Le et al., 2005a,b).

Last, we directly examined mRNA levels of Egr2 target genes involved in myelination by quantitative RT-PCR on P14 sciatic nerve. We examined several target genes of Egr2 transcriptional regulation, as evidenced by the presence of Egr2 binding sites
(Maier et al., 2003; Leblanc et al., 2005; LeBlanc et al., 2006), increased expression in Schwann cells with forced Egr2 expression (Nagarajan et al., 2001), and decreased mRNA levels present in Egr2 hypomorphic mice (Le et al., 2005a). As expected, Egr $2 \mathrm{mRNA}$ levels were identical in wild-type and $E g r 2^{1268 N / I 268 N}$ nerves, in agreement with Egr2 protein levels (Fig. $1 A)$ and confirming that transcriptional regulation of the $E g r 2^{I 268 N}$ knock-in locus remains intact. In contrast, mRNA levels of the Egr2 target genes Pmp22, Periaxin, $\mathrm{Mpz}$, and Gjb1 (Connexin 32) are all diminished twofold to fivefold (Fig. 4E). These results indicate that Egr2 $2268 \mathrm{~N} / 1268 \mathrm{~N}$ mice have congenital hypomyelination with most Schwann cells arrested in the promyelinating phase, and lack of transcriptional activation of multiple Egr2 target genes associated with myelination. This argues that Egr2-Nab1/2 complexes are critical transcriptional regulators of Schwann cell development, that loss of the interaction between Egr2 and Nab proteins is sufficient to recapitulate loss of either Egr2 or Nab1/2, and that the lack of functional Egr2-Nab complexes is responsible for the severe peripheral neuropathy in patients with the Egr2 ${ }^{I 268 N}$ mutation.

\section{Egr $2^{I 268 N}$ mice manifest low penetrance} defects in lower cranial nerve development

Aside from its function in peripheral nerve development, Egr2 is also important in hindbrain development, and Egr2 null mice have loss of rhombomeres 3 and 5 and typically die at birth (Schneider-Maunoury et al., 1993). In contrast, hindbrain abnormalities are variable in Egr2 hypomorphic mice, and do not occur in Nab1/2 null mice (Le et al., 2005a,b). We performed neurofilament immunostaining on E10.5 embryos and examined hindbrain segmentation in Egr2 $2^{1268 N / I 268 N}$ mice. Unlike Egr2 null and hypomorphic mice, Egr2 ${ }^{1268 N / I 268 N}$ mice did not show absence of rhombomeres 3 or 5 , or changes in the projection pattern of cranial nerves V or VII. However, 33\% of Egr $2^{I 268 N / I 268 N}$ mice had partial or complete fusion of cranial nerves IX and X (Fig. $5 A-C)$. Surprisingly, $15 \%$ of Egr2 ${ }^{2268 N /+}$ mice showed a similar defect in cranial nerve IX/X development, indicating that this abnormality can be inherited as a dominant trait.

Nab1/2 null mice have several abnormalities in addition to hypomyelination, including epidermal hyperplasia and hyperkeratosis (Le et al., 2005b). In contrast, the skin was histologically normal in $E g r 2^{2268 N / I 268 N}$ mice, indicating that this aspect of Nab1/2 function is likely mediated through other Egr family members (supplemental Fig. 2, available at www.jneurosci.org as supplemental material).

These data indicate that though hindbrain development is abnormal in a minority of Egr $2^{I 268 N / 1268 N}$ mice, it cannot be responsible for the uniformly rapid decline and lethality in these mice.

Nerve electrophysiology in $E g r 2^{1268 N / I 268 N}$ mice showed slow nerve conduction velocity with evidence of conduction block Patients with the Egr2 ${ }^{I 268 N / I 268 N}$ mutation have congenital hypomyelination with severe slowing of nerve conduction velocity of 
$\sim 3 \mathrm{~m} / \mathrm{s}$ (Szigeti et al., 2007). We performed electrophysiology on Egr2 $2^{\text {I268N/I268N }}$ mice between P18 and P21, in animals that showed severe lower extremity weakness or paralysis (Fig. 6A,B). Nerve conduction velocity was markedly slowed in Egr $2^{I 268 N / I 268 N}$ mice, with an average nerve conduction velocity of $\sim 3 \mathrm{~m} / \mathrm{s}$, significantly slower than wild-type or Egr ${ }^{1268 \mathrm{~N} /+}$ mice at this age $(\sim 20 \mathrm{~m} / \mathrm{s})$ (Fig. 6C). Interestingly, Egr $2^{I 268 N / I 268 N}$ mice showed marked temporal dispersion and diminished CMAP amplitude on proximal stimulation, with relative preservation of distal CMAP amplitude and duration (distal/proximal CMAP amplitude ratio: $1.22 \pm 0.3$ in wild type vs $0.46 \pm 0.3$ in Egr $\left.2^{\text {I268N/I268N }} ; p<0.001\right)$. This suggests that congenital hypomyelination in Egr $2^{\text {I268N/I268N }}$ mice leads to variable slowing and loss of action potential conduction along the course of the nerve, and that conduction block likely contributes to the rapidly progressive weakness in these animals.

\section{Nodal structure is abnormal in sciatic nerve from $\mathrm{Egr} 2^{I 268 \mathrm{~N} / \mathrm{I268N}}$ mice}

Disruption of node of Ranvier organization is a common finding in both acute demyelination (Rasband et al., 1998) and chronic dysmyelination (for review, see Poliak and Peles, 2003). In rodents, peripheral nodes typically express the voltage-gated sodium channel Nav1.2 at birth, but switch during development (before P7) to express Nav1.6 (Rasband and Trimmer, 2001). We found that Nav1.6 is present in nodes from $\mathrm{P} 14$ sciatic nerve of Egr $2^{I 268 N / I 268 N}$ mice (Fig. $7 A, B$ ), whereas Nav1.2 is absent (data not shown), indicating that the normal developmental switch between these channels is intact. However, staining with Caspr (a marker of the paranode) appeared dispersed and was occasionally diminished or absent. Furthermore Kv1.1, which is normally localized to the juxtaparanode (Fig. 7C), was found in all cases to either (1) overlap with Caspr indicating spread into the paranode (Fig. 7D); (2) be dispersed into the internode (Fig. $7 E$ ); or (3) be completely absent (Fig. $7 F, G$ ). These abnormalities are similar to that seen in other models of inherited dysmyelination (Poliak and Peles, 2003; Ulzheimer et al., 2004; Devaux and Scherer, 2005) and likely contribute to the alterations in nerve electrophysiology seen in the Egr $2^{I 268 N / I 268 N}$ mice.

$E g r 2^{I 268 N / I 268 N}$ mice have terminal sprouting without axon loss or denervation of neuromuscular junctions

Weakness and sensory loss in patients with demyelinating CMT is typically associated with secondary axon loss (Sancho et al., 1999; Krajewski et al., 2000). Therefore, we performed axonal counts on sciatic nerves from wild-type and Egr $2^{I 268 N / I 268 N}$ mice.
Wild-Type
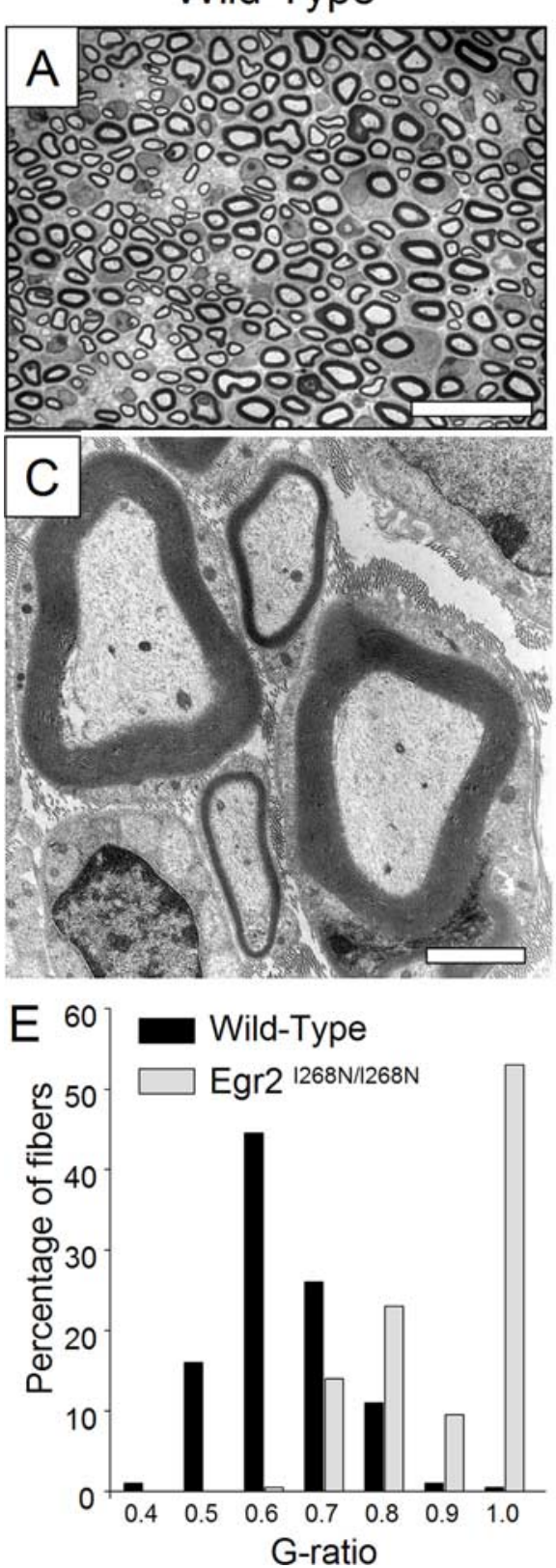

Figure 3. Congenital hypomyelination in Egr2 ${ }^{1268 N / 268 N}$ mice. Toluidine-blue-stained plastic sections of sciatic nerves from wild-type $(\boldsymbol{A}, \boldsymbol{C})$ and $E g r 2^{1268 N / 1268 N}(\boldsymbol{B}, \boldsymbol{D}, \boldsymbol{F})$ mice showed many fewer myelinated axons, frequent $S c h w a n n$ cells with enlarged cytoplasm and irregularly shaped nuclei, and decreased myelin thickness in Egr2 ${ }^{1268 \mathrm{~N} / 1268 \mathrm{~N}}$ nerves. No onion bulbs were present. Electron microscopy of P14 sciatic nerve again showed large axons with no myelin or decreased myelin thickness and ensheathing Schwann cells (scale bars: $\boldsymbol{A}, \boldsymbol{B}, 20 \mu \mathrm{m} ; \boldsymbol{C}, \boldsymbol{D}, \boldsymbol{F}, 2 \mu \mathrm{m})$. $\boldsymbol{E}$, Histogram of g ratios from sciatic nerve axons $>1 \mu \mathrm{m}$ of the wild-type
versus Egr2 ${ }^{1268 N / 1268 N}$ mice showed significant thinning of myelin sheaths ( $p<0.001$ Mann-Whitney rank sum test).
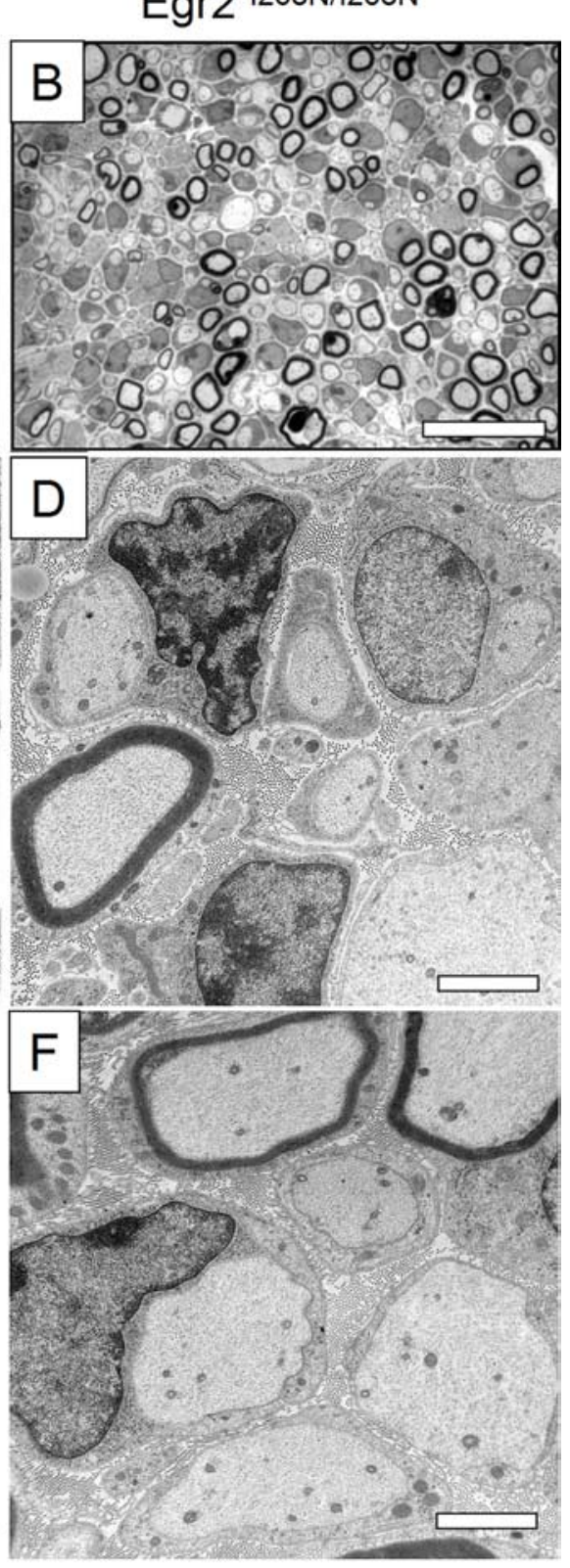

There was no difference in the number of sciatic axons $(>1 \mu \mathrm{m})$ in wild-type versus Egr $2^{I 268 N / I 268 N}$ mice at either P14 (before onset of severe weakness) or P18 (at which time the hindlimbs are essentially paralyzed) (Fig. $8 \mathrm{~A}$ ). Given that the sciatic nerve is a proximal site and predominantly sensory in mice, we examined the innervation of NMJs in the EDL and diaphragm muscles in P18 Egr $2^{I 268 N / I 268 N}$ mice. Egr $2^{\mathrm{I} 268 \mathrm{~N} /+}$ mice were crossed with Thyl-YFP transgenic mice (Feng et al., 2000), and Egr $2^{\text {I268N/I268N }}$ :Thy1-YFP mice were generated to visualize motor axons, with costaining for $\alpha$-bungarotoxin to visualize postsynaptic acetylcholine receptors. There was no evidence of axon degeneration, retraction or unoccupied NMJs in Egr $2^{I 268 N / I 268 N}$ 


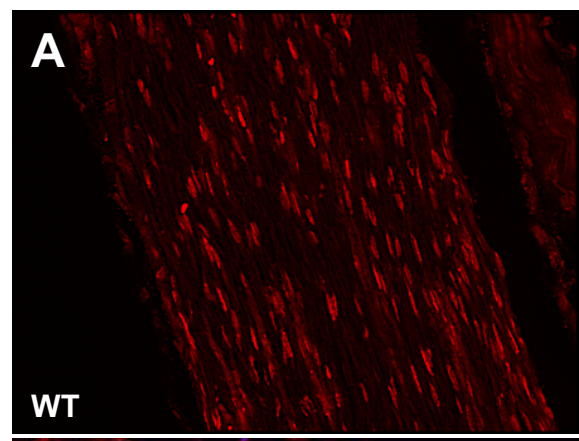

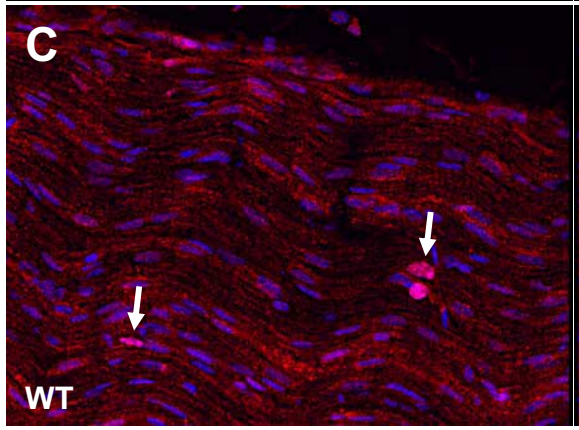

$1268 \mathrm{~N}$
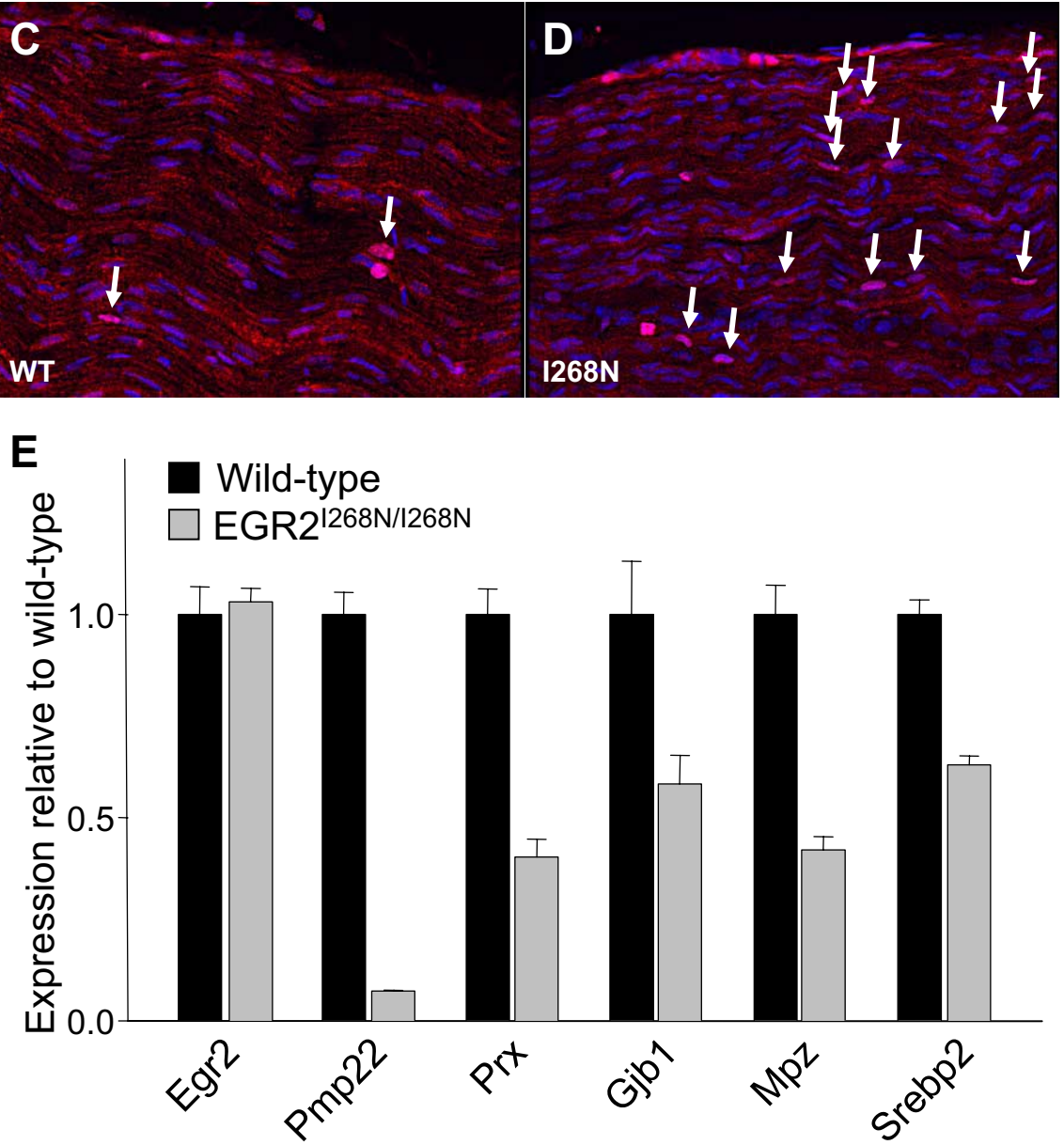

Figure 4. Schwann cells in Egr2 $2^{1268 N / 1268 N}$ mice show persistent proliferation and decreased expression of multiple genes essential for proper myelination. Immunostaining for the promyelinating Schwann cell marker Pou3f1 $(\boldsymbol{A}, \boldsymbol{B})$ showed increased numbers of positive nuclei in the Egr2 ${ }^{1268 N / 268 N}$ sciatic nerve $(I 268 \mathrm{~N})$ compared with wild type (WT). Quantification showed $\mathrm{WT}=39 \pm 7$ nuclei/ $0.01 \mathrm{~mm}^{2}$ versus Egr2 $2^{1268 \mathrm{~N} / 1268 \mathrm{~N}}=68 \pm 7$ nuclei/0.01 mm $\mathrm{mm}^{2}(p<0.001$, paired $t$ test). Additionally, significantly more proliferating Schwann cells as measured by Ki67 staining are observed in Egr2 ${ }^{1268 N / 1268 \mathrm{~N}}$ nerves than in wildtype nerves $(6.8 \%$ vs $3.6 \% ; p<0.05$, paired $t$ test; $\boldsymbol{C}, \boldsymbol{D})$. Quantitative RT-PCR analysis showed that whereas Egr2 transcript levels themselves are normal, expression of several other myelin genes are significantly decreased. The decrement was most pronounced for Pmp22 ( 7\% of normal transcript levels), and was between 40 and $60 \%$ of normal for periaxin (Prx), connexin 32 (Gjb1), myelin protein zero (Mpz), and sterol regulatory element binding protein 2 (Srebp2).

mice despite the fact that the EDL is essentially paralyzed at P18 (Fig. 8 B). Interestingly, NMJs from Egr2 $2^{I 268 N / I 268 N}$ mice showed extensive sprouting at P18 (Fig. $8 E, F$ ) which is never observed in wild-type mice (Fig. $8 D$ ), nor in Egr $2^{I 268 N / I 268 N}$ at P14 before the onset of severe weakness (data not shown). NMJ sprouting is known to occur after blockage of action potentials with tetrodotoxin (Brown and Ironton, 1977), in the med/med mice which have loss of Nav1.6 function (Duchen, 1970; Burgess et al., 1995), or inhibition of presynaptic NMJ function with botulinum toxin
(Pestronk and Drachman, 1978). It is believed to be mediated by secreted factors from muscle fibers in which electrical activity is lost due to structural or functional (i.e., tetrodotoxin) denervation. These data strongly support that the rapidly progressive weakness in Egr $2^{I 268 N / I 268 N}$ mice is due to conduction failure either at proximal sites along the nerve, or at the NMJ itself.

\section{Discussion}

In this study we have described the development of an animal model of human CMT4E, due to the recessively inherited I268N mutation in Egr2. We found that this mutation leads to complete loss of interaction between Egr2 and the Nab transcriptional coregulatory proteins, and produces severe congenital hypomyelination in mice, clearly demonstrating that the Egr2-Nab complex is the critical transcriptional regulator of Schwann cell development. Furthermore we found that the weakness and premature death in these animals is due to conduction failure rather than axonal loss, confirming a second important mechanism that results in weakness and sensory loss which may play a prominent role in congenital hypomyelinating neuropathy $(\mathrm{CHN})$.

\section{The Egr2-Nab complex is a critical for transcriptional regulation of peripheral myelination}

Transcription factors typically function as components of large multimolecular complexes to regulate the complex gene regulatory programs necessary for proper cellular development and maintenance of differentiation. This study, together with many others, supports the important role of Egr2 as a transcriptional regulator of myelin development (Jessen and Mirsky, 2002), but furthermore strongly confirms that it is the Egr2-Nab complex, rather than Egr2 alone, which is critical for myelin development (Le et al., 2005a). Using in vitro reporter assays $\mathrm{Nab}$ proteins were first posited to act as corepressors of Egr function (Russo et al., 1995; Svaren et al., 1996), or alternatively coactivators depending on the promoter context (Warner et al., 1999; Sevetson et al., 2000). Simply by disrupting the interaction between Egr2 and $\mathrm{Nab}$ proteins with the human disease mutation I268N we were able to largely recapitulate the hypomyelinating phenotype of either the Egr2 hypomorph, or the Nab1/2 null mice (Le et al., 2005b). Schwann cells in the Egr2 ${ }^{I 268 N / I 268 N}$ mice largely remain in a promyelinating phase, where they continue to express the Pou3f1 transcription factor and proliferate. Furthermore, all of the Egr2-Nab target genes investigated were expressed at low levels, supporting that although Nab proteins frequently function as transcriptional corepressors on artificial 

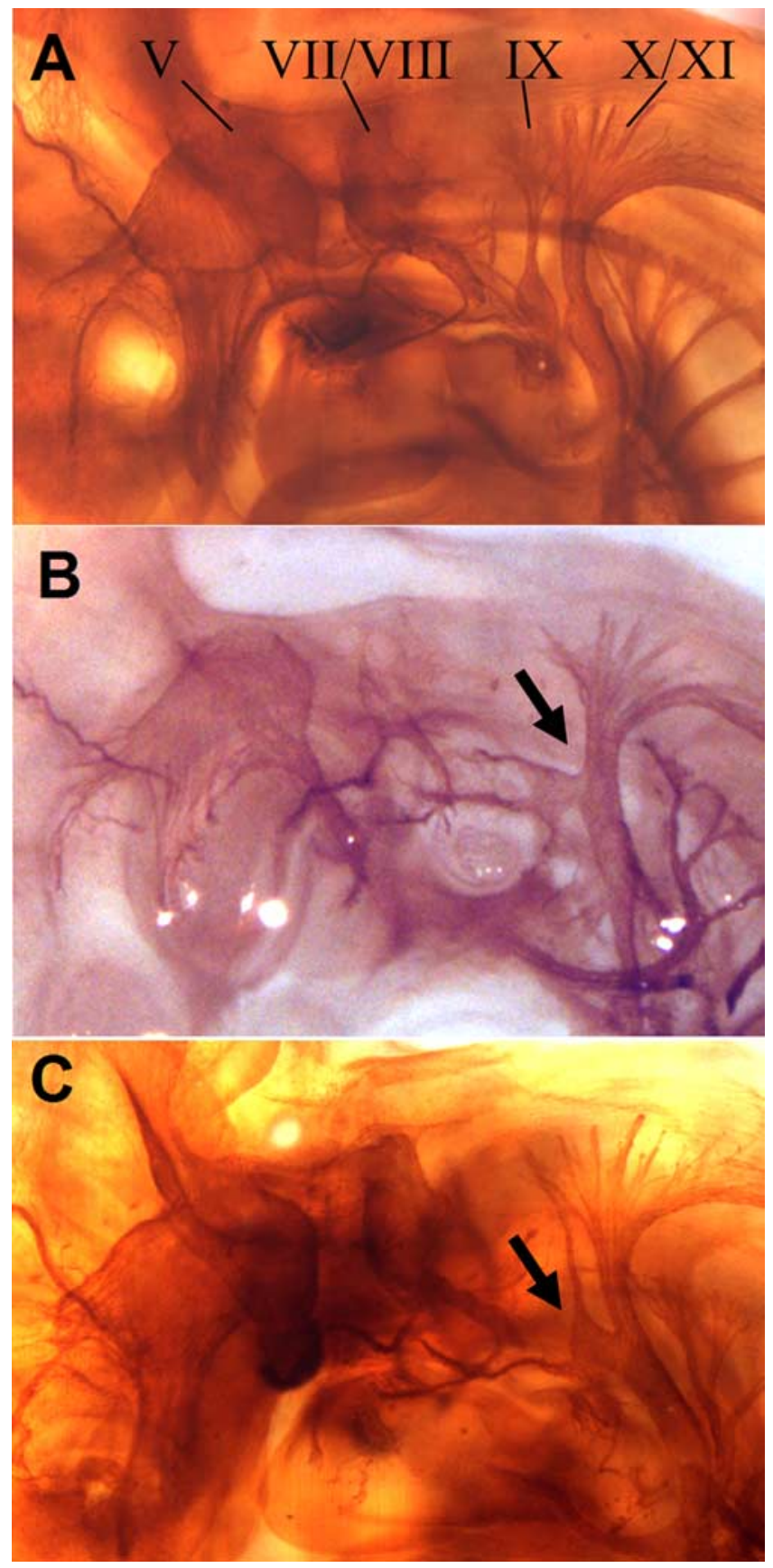

Figure 5. $\quad E g r 2^{1268 N}$ mice manifest low penetrance defects in lower cranial nerve development. $\boldsymbol{A}-\boldsymbol{C}$, Neurofilament staining of embryonic day 10.5 mice showed either complete or partial fusion of cranial nerve IX with the X/XI complex in Egr2 ${ }^{1268 N / 268 N}$ mice (arrow in B, C), compared with wild-type mice $(\boldsymbol{A})$. This endophenotype was observed in $15 \%$ of $\mathrm{Egr2}{ }^{1268 \mathrm{~N} /+}$ embryos and $33 \%$ of $E g r 2^{1268 N / 268 N}$ embryos.

promoter systems, in myelin development Nab proteins primarily function as coactivators.

In contrast to the role of Egr2-Nab complexes in nerve development, we observed the unexpected finding that there are abnormalities in lower hindbrain development in mice with either one or two I268N alleles, and the frequency of these defects appeared to be dose dependent (i.e., $\sim 15 \%$ with one I $268 \mathrm{~N}$ allele, and $\sim 30 \%$ with two I $268 \mathrm{~N}$ alleles). This raises several interesting points: first, given that none of the Egr2 ${ }^{1268 N /+}$ mice die prematurely despite the fact that $15 \%$ have similar hindbrain defects, abnormal hindbrain function

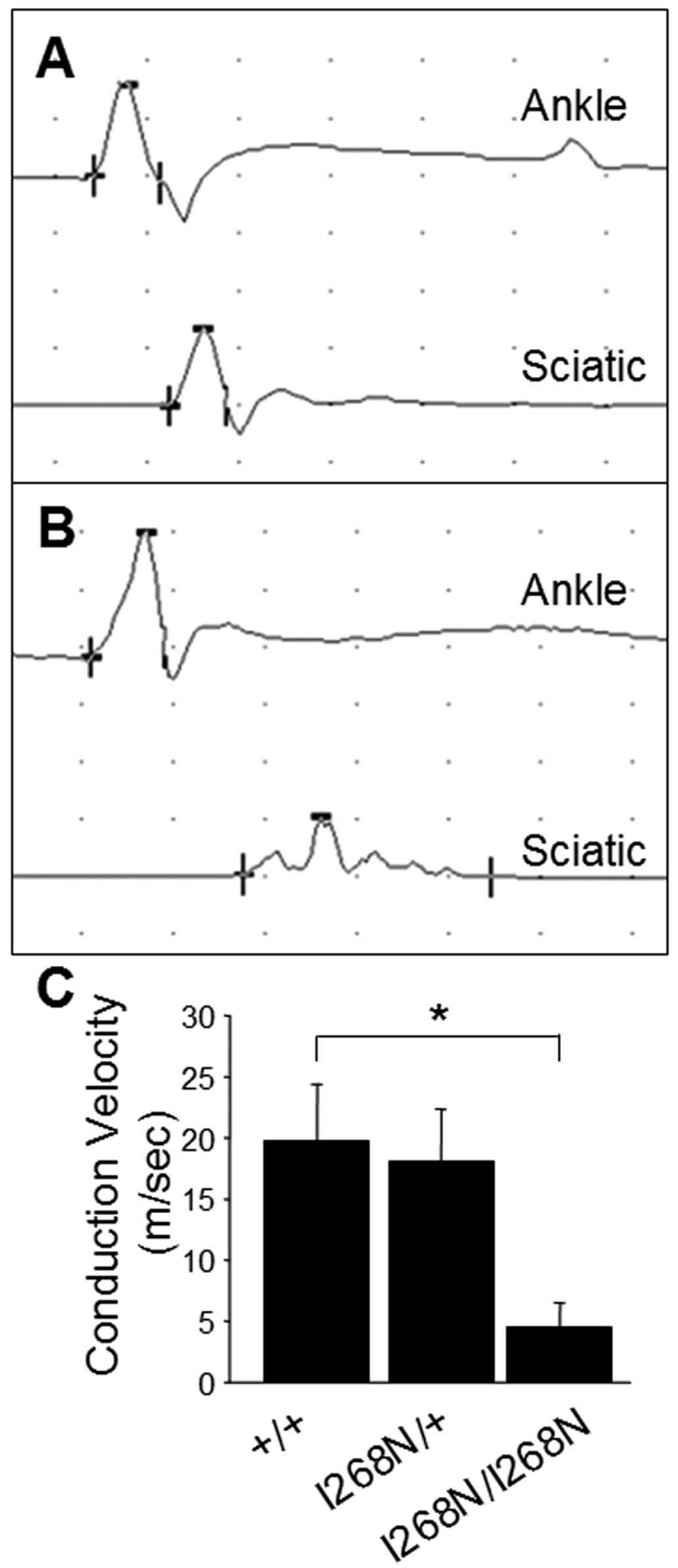

Figure 6. Nerve electrophysiology in Egr2 $2^{1268 N / 268 N}$ mice showed slow nerve conduction velocity with temporal dispersion and/or conduction block. $A$, Representative traces of CMAPs from foot flexor muscles with proximal (sciatic notch) and distal (ankle) stimulation of wild-type and $E g r 2^{1268 N / 268 N}$ mice. Note severe slowing of conduction velocity in Egr2 ${ }^{1268 N / 268 N}$ nerves, temporal dispersion of CMAPs, and relative preservation of the distal CMAP amplitude. Gradations $(\boldsymbol{A})$ : horizontal $=1 \mathrm{~ms}$, vertical $=1 \mathrm{mV} ;(\boldsymbol{B})$ : horizontal $=2 \mathrm{~ms}$, vertical $=0.5 \mathrm{mV}$. C, Nerve conduction velocity was significantly decreased in Egr2 ${ }^{1268 \mathrm{~N} / 1268 \mathrm{~N}}$ mice compared with wild type ( $t$ test, $p<0.001$ ).

is not the likely cause of lethality in Egr $2^{I 268 N / I 268 N}$ mice; second, the dose responsive nature of the hindbrain defect suggests that $\mathrm{Nab}$ transcriptional repression plays a predominant role in determining this phenotype. This then explains the 

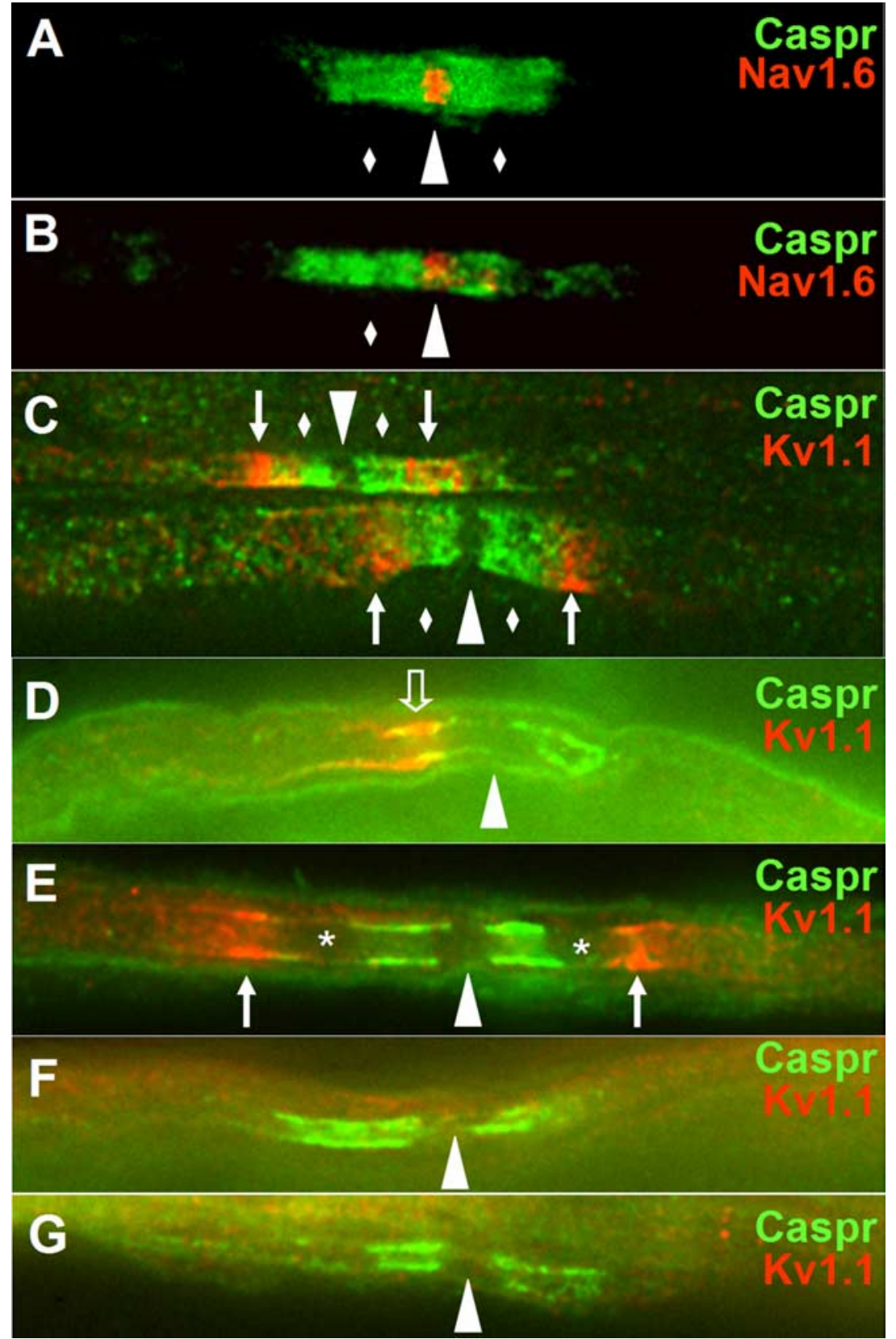

Figure 7. Altered node of Ranvier organization in Egr2 $2^{1268 N / 268 N}$ mice. A, Overlap image of teased nerve from a wild-type mouse stained with Caspr (green) and Nav1.6 (red) showing normal appearance of node (arrowhead) and paranode (diamonds). $B$, Nodes in the Egr2 ${ }^{1268 N / 268 N}$ mice uniformly stained with Nav1.6 similarly to wild type. The paranode on the right in this example shows diminished Caspr staining. C, Teased nerve from a wild-type mouse stained with Caspr (green) and Kv1.1 (red) showing normal appearance of node (arrowhead), paranodal Caspr (diamonds), and juxtaparanodal Kv1.1 (arrows). None of the nodes from Egr2 ${ }^{1268 N / 268 N}$ mice appeared normal, and displayed various abnormalities including: (D) overlapping of Caspr and Kv1.1 (open arrow) with absence of Kv1.1 on one side of the node; $(\boldsymbol{E})$ dispersion of juxtaparanodal Kv1.1 into the internodes with a space present between Caspr and Kv1.1 (asterisks); $(\boldsymbol{F}, \boldsymbol{G})$ absence of Kv1.1 staining with lengthening of Caspr staining and widening of the node itself.

dominant inheritance of this endophenotype: presumably $\mathrm{Nab}$ proteins are repressing Egr2-dependent transcription of certain genes involved in hindbrain development similar to that observed in zebrafish (Mechta-Grigoriou et al., 2000). $\mathrm{Nab}$ repression of Egr2 activity is partly lost in the Egr $2^{\text {I268N/+ }}$ mice, and completely lost in Egr2 ${ }^{I 268 N / I 268 N}$ mice, leading to the dose-response relationship. Interestingly a similar observation was made in a recent report of another Egr 2 knock-in mutation $\left(E g r 2^{I 268 F}\right)$ which found persistent expression of
Egr2 target genes in developing hindbrain suggesting gain of function of the Egr2 ${ }^{I 268 F}$ allele (Desmazières et al., 2008).

Axonal loss, conduction block, and neuromuscular junction abnormalities in CMT

One of the remarkable aspects of hereditary disorders of myelin is that patients can have significant disorders of myelin and slow nerve conduction velocity, but not have symptoms unless there is a secondary effect on axonal or synaptic function. This is illustrated well in the case of mutations in ARHGEF10, in which a large family has been described that has diffuse slowing of $\mathrm{NCV}$ and demyelination, but minimal symptoms (Verhoeven et al., 2003). Secondary axonal loss appears to be the predominant mechanism by which patients develop disability from distal sensory loss and weakness in CMT1A, both in human patients (Krajewski et al., 2000) and mouse models of the disease (Sancho et al., 1999). However, conduction block (the loss of action potential propagation along an axon) is observed in some forms of CMT (particularly CMTX and CMT1B), and may also contribute to symptoms (Lewis et al., 2000; Pareyson et al., 2006). Additionally, abnormalities in the NMJ have been observed at both the structural and functional level in several animal models of CMT, although the degree to which this occurs in patients remains unclear (Yin et al., 2004; Court et al., 2008). We found that the NMJs of Egr $2^{I 268 N / I 268 N}$ mice show normal innervation with marked terminal sprouting that develops in concert with the onset of severe weakness. Terminal sprouting is typically observed after structural or functional denervation, and is likely mediated by muscle derived signals to ultimately produce collateralization (Tam and Gordon, 2003). Given that terminal sprouting can be observed after treatment with either tetrodotoxin (Brown and Ironton, 1977) or botulinum toxin (Pestronk and Drachman, 1978), we cannot be certain whether the sprouting in the Egr $2^{I 268 N / I 268 N}$ mice is due to axonal or synaptic dysfunction or both. However, the segmental defects in myelination and preserved distal CMAP amplitudes argue more for an axonal origin, i.e., conduction block. Our data support that axonal dysfunction can contribute to disability in a mouse model of inherited neuropathy, and suggests that a similar mechanism may be involved in congenital hypomyelinating neuropathy in humans as well.

\section{Mouse models of congenital hypomyelinating neuropathy} Egr $2^{\text {I268N/I268N }}$ mice are now the second animal model produced of $\mathrm{CHN}$ and is the only one in which a missense mutation found in human patients at normal gene dosage recapitulates disease, in 
contrast to other $\mathrm{CHN}$ models using knockdown of Egr2 (Topilko et al., 1994; Le et al., 2005a), or overexpression of myelin protein zero (Wrabetz et al., 2000). These models share the expected features of human $\mathrm{CHN}$ : severe decrease or absence in peripheral myelin formation from birth, with associated early onset or congenital weakness and sensory loss (Houlden and Reilly, 2006). However, while mice overexpressing MPZ have a similar degree of hypomyelination histologically, they live an apparently normal lifespan in contrast to mice with Egr2-Nab dysfunction, which uniformly die within 3 weeks of birth (Wrabetz et al., 2000). The origin of this difference remains unclear, but we suspect differences in genetic background may play a role, possibly influencing the conduction block and/or NMJ dysfunction seen in Egr2 ${ }^{I 268 \mathrm{~N} / I 268 \mathrm{~N}}$ mice. Interestingly Egr2 and Nab proteins are expressed in peripheral neurons (in contrast to MPZ), suggesting the alternative explanation that loss of Egr2-Nab function in peripheral neurons diminishes their ability to compensate for hypomyelination and continue propagating action potentials. Further studies of Egr $2^{I 268 N / I 268 N}$ mice on different genetic backgrounds, as well as more detailed analysis of Egr2-Nab in regulating nodal components in peripheral neurons will help to answer this question.

Despite being a relatively common disease associated with significant disability, no treatments which can slow or reverse the progression of hereditary peripheral neuropathies are currently available. Given the recent evidence that progesterone antagonists are protective in a rat model of CMT1A by modulating gene transcription (Sereda et al., 2003), a detailed understanding of transcriptional pathways altered in models such as the Egr2 ${ }^{I 268 N / I 268 N}$ mice may be useful in designing therapeutic interventions in the future.

\section{References}

Abdulkadir SA, Carbone JM, Naughton CK, Humphrey PA, Catalona WJ, Milbrandt J (2001) Frequent and early loss of the EGR1 corepressor NAB2 in human prostate carcinoma. Hum Pathol 32:935-939.

Bermingham JR Jr, Scherer SS, O'Connell S, Arroyo E, Kalla KA, Powell FL, Rosenfeld MG (1996) Tst-1/Oct-6/SCIP regulates a unique step in peripheral myelination and is required for normal respiration. Genes Dev 10:1751-1762.

Brown MC, Ironton R (1977) Motor neurone sprouting induced by prolonged tetrodotoxin block of nerve action potentials. Nature 265:459-461.

Burgess DL, Kohrman DC, Galt J, Plummer NW, Jones JM, Spear B, Meisler MH (1995) Mutation of a new sodium channel gene, Scn8a, in the mouse mutant 'motor endplate disease'. Nat Genet 10:461-465.

Charcot JM, Marie P (1886) Sur une forme particuliere d'atrophie musculaire progressive souvent familiale debutant par les pieds et les jambes et atteignant plus tard les mains. Rev Med 6:97-138.
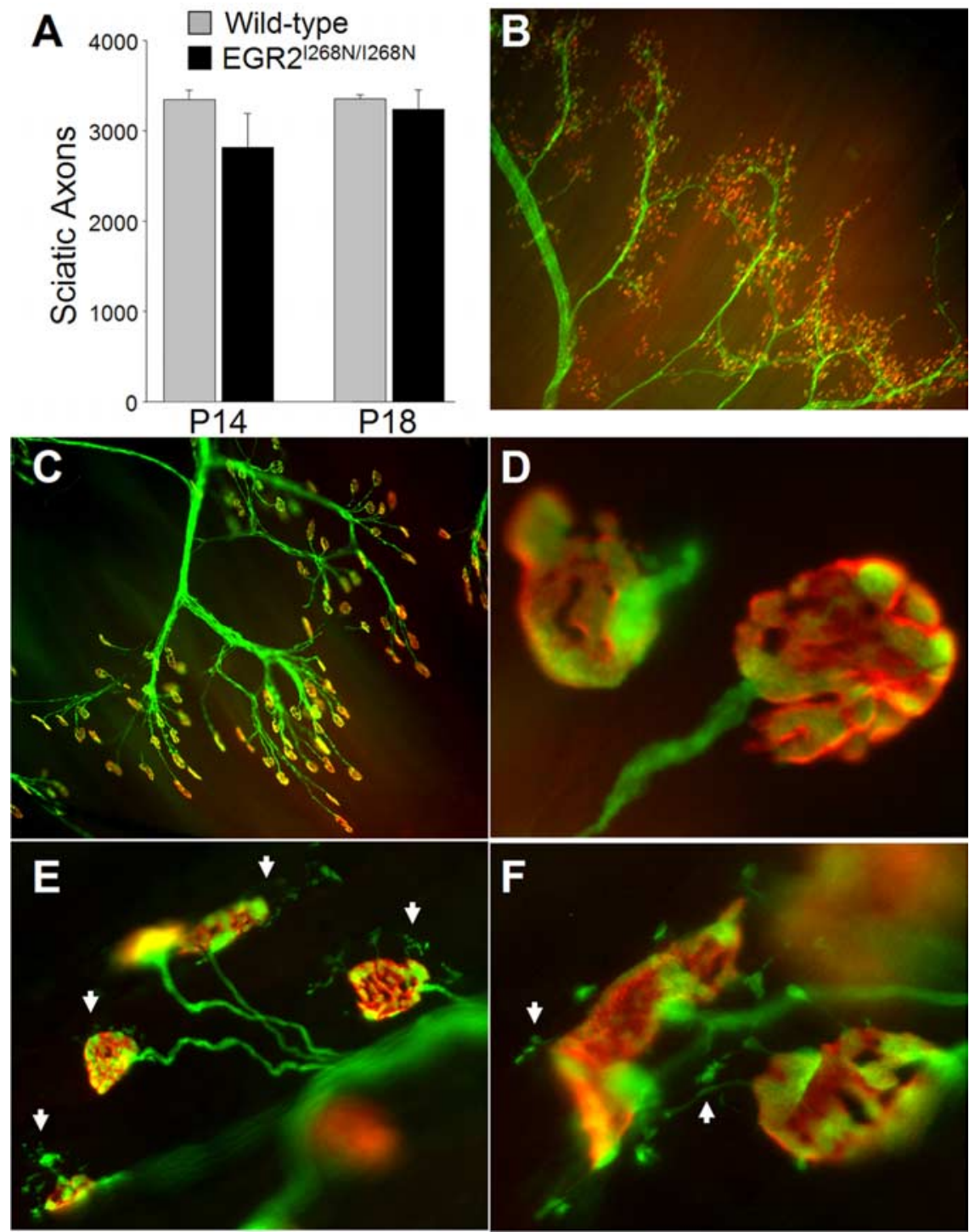

Figure 8. $E g r 2^{1268 N / 1268 N}$ mice with severe weakness have terminal sprouting without axon loss or denervation of neuromuscular junctions. A, Axon counts $(>1 \mu \mathrm{m})$ from sciatic nerve of wild-type (WT) and Egr $2^{1268 N / 1268 N}$ mice at P14 and P18. In the time ctions were visualized by crossing Egr2 ${ }^{1268 N}$ mice to Thy1-YFP mice that express YFP in motor axons (green). Acetyl-

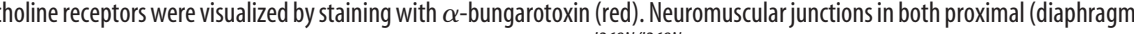
B) and distal (extensor digitorum longus; $C$ ) muscles from P18 Egr2 $2^{1268 N / 268 N} \times$ Thy1-YFP mice were fully occupied at a time the mice showed near complete hindlimb paralysis. Higher magnification images revealed marked terminal sprouting from NMJs in Egr2 $^{1268 N / 268 N} \times$ Thy1-YFP mice $(\boldsymbol{E}, \boldsymbol{F})$, which was never seen in wild-type mice $(\boldsymbol{D})$ and is consistent with conduction block.
Court FA, Brophy PJ, Ribchester RR (2008) Remodeling of motor nerve terminals in demyelinating axons of periaxin-null mice. Glia 56:471-479. Decker L, Desmarquet-Trin-Dinh C, Taillebourg E, Ghislain J, Vallat JM, Charnay P (2006) Peripheral myelin maintenance is a dynamic process requiring constant Krox20 expression. J Neurosci 26:9771-9779.

Desmazières A, Decker L, Vallat JM, Charnay P, Gilardi-Hebenstreit P (2008) Disruption of Krox20-Nab interaction in the mouse leads to peripheral neuropathy with biphasic evolution. J Neurosci 28:5891-5900.

Devaux JJ, Scherer SS (2005) Altered ion channels in an animal model of Charcot-Marie-Tooth disease type IA. J Neurosci 25:1470-1480.

Duchen LW (1970) Hereditary motor end-plate disease in the mouse: light and electron microscopic studies. J Neurol Neurosurg Psychiatry 33:238-250.

Feng G, Mellor RH, Bernstein M, Keller-Peck C, Nguyen QT, Wallace M, Nerbonne JM, Lichtman JW, Sanes JR (2000) Imaging neuronal subsets in transgenic mice expressing multiple spectral variants of GFP. Neuron 28:41-51. 
Hahn AF, Chang Y, Webster HD (1987) Development of myelinated nerve fibers in the sixth cranial nerve of the rat: a quantitative electron microscope study. J Comp Neurol 260:491-500.

Houlden H, Reilly MM (2006) Molecular genetics of autosomal-dominant demyelinating Charcot-Marie-Tooth disease. Neuromolecular Med $8: 43-62$.

Jessen KR, Mirsky R (2002) Signals that determine Schwann cell identity. J Anat 200:367-376.

Krajewski KM, Lewis RA, Fuerst DR, Turansky C, Hinderer SR, Garbern J, Kamholz J, Shy ME (2000) Neurological dysfunction and axonal degeneration in Charcot-Marie-Tooth disease type 1A. Brain 123:1516-1527.

Le N, Nagarajan R, Wang JY, Araki T, Schmidt RE, Milbrandt J (2005a) Analysis of congenital hypomyelinating Egr2Lo/Lo nerves identifies Sox2 as an inhibitor of Schwann cell differentiation and myelination. Proc Natl Acad Sci U S A 102:2596-2601.

Le N, Nagarajan R, Wang JY, Svaren J, LaPash C, Araki T, Schmidt RE, Milbrandt J (2005b) Nab proteins are essential for peripheral nervous system myelination. Nat Neurosci 8:932-940.

Leblanc SE, Srinivasan R, Ferri C, Mager GM, Gillian-Daniel AL, Wrabetz L, Svaren J (2005) Regulation of cholesterol/lipid biosynthetic genes by Egr2/Krox20 during peripheral nerve myelination. J Neurochem 93:737-748.

LeBlanc SE, Jang SW, Ward RM, Wrabetz L, Svaren J (2006) Direct regulation of myelin protein zero expression by the Egr2 transactivator. J Biol Chem 281:5453-5460.

Lewis RA, Sumner AJ, Shy ME (2000) Electrophysiological features of inherited demyelinating neuropathies: a reappraisal in the era of molecular diagnosis. Muscle Nerve 23:1472-1487.

Lupski JR (1997) Charcot-Marie-Tooth disease: a gene-dosage effect. Hosp Pract (Off Ed) 32:83-84, 89-91, 94-95 passim.

Maier M, Castagner F, Berger P, Suter U (2003) Distinct elements of the peripheral myelin protein 22 (PMP22) promoter regulate expression in Schwann cells and sensory neurons. Mol Cell Neurosci 24:803-817.

Mechta-Grigoriou F, Garel S, Charnay P (2000) Nab proteins mediate a negative feedback loop controlling Krox-20 activity in the developing hindbrain. Development 127:119-128.

Mirsky R, Jessen KR (1996) Schwann cell development, differentiation and myelination. Curr Opin Neurobiol 6:89-96.

Nagarajan R, Svaren J, Le N, Araki T, Watson M, Milbrandt J (2001) EGR2 mutations in inherited neuropathies dominant-negatively inhibit myelin gene expression. Neuron 30:355-368.

Nicholson GA (2006) The dominantly inherited motor and sensory neuropathies: clinical and molecular advances. Muscle Nerve 33:589-597.

Pareyson D, Scaioli V, Laurà M (2006) Clinical and electrophysiological aspects of Charcot-Marie-Tooth disease. Neuromolecular Med 8:3-22.

Pestronk A, Drachman DB (1978) Motor nerve sprouting and acetylcholine receptors. Science 199:1223-1225.

Poliak S, Peles E (2003) The local differentiation of myelinated axons at nodes of Ranvier. Nat Rev Neurosci 4:968-980.

Rasband MN, Trimmer JS (2001) Developmental clustering of ion channels at and near the node of Ranvier. Dev Biol 236:5-16.

Rasband MN, Trimmer JS, Schwarz TL, Levinson SR, Ellisman MH, Schachner M, Shrager P (1998) Potassium channel distribution, clustering, and function in remyelinating rat axons. J Neurosci 18:36-47.

Russo MW, Matheny C, Milbrandt J (1993) Transcriptional activity of the zinc finger protein NGFI-A is influenced by its interaction with a cellular factor. Mol Cell Biol 13:6858-6865.

Russo MW, Sevetson BR, Milbrandt J (1995) Identification of NAB1, a repressor of NGFI-A and Krox20 mediated transcription. Proc Natl Acad Sci U S A 92:6873-6877.

Ryu EJ, Wang JY, Le N, Baloh RH, Gustin JA, Schmidt RE, Milbrandt J (2007) Misexpression of Pou3f1 results in peripheral nerve hypomyelination and axonal loss. J Neurosci 27:11552-11559.
Sancho S, Magyar JP, Aguzzi A, Suter U (1999) Distal axonopathy in peripheral nerves of PMP22-mutant mice. Brain 122:1563-1577.

Schneider-Maunoury S, Topilko P, Seitandou T, Levi G, Cohen-Tannoudji M, Pournin S, Babinet C, Charnay P (1993) Disruption of Krox-20 results in alteration of rhombomeres 3 and 5 in the developing hindbrain. Cell 75:1199-1214.

Sereda M, Griffiths I, Pühlhofer A, Stewart H, Rossner MJ, Zimmerman F, Magyar JP, Schneider A, Hund E, Meinck HM, Suter U, Nave KA (1996) A transgenic rat model of Charcot-Marie-Tooth disease. Neuron 16:1049-1060.

Sereda MW, Meyer zu Hörste G, Suter U, Uzma N, Nave KA (2003) Therapeutic administration of progesterone antagonist in a model of CharcotMarie-Tooth disease (CMT-1A). Nat Med 9:1533-1537.

Sevetson BR, Svaren J, Milbrandt J (2000) A novel activation function for NAB proteins in EGR-dependent transcription of the luteinizing hormone beta gene. J Biol Chem 275:9749-9757.

Shy ME (2004) Charcot-Marie-Tooth disease: an update. Curr Opin Neurol 17:579-585.

Suter U, Scherer SS (2003) Disease mechanisms in inherited neuropathies. Nat Rev Neurosci 4:714-726.

Svaren J, Meijer D (2008) The molecular machinery of myelin gene transcription in Schwann cells. Glia 56:1541-1551.

Svaren J, Sevetson BR, Apel ED, Zimonjic DB, Popescu NC, Milbrandt J (1996) NAB2, a corepressor of NGFI-A (Egr-1) and Krox20, is induced by proliferative and differentiative stimuli. Mol Cell Biol 16:3545-3553.

Szigeti K, Wiszniewski W, Saifi GM, Sherman DL, Sule N, Adesina AM, Mancias P, Papasozomenos SCh, Miller G, Keppen L, Daentl D, Brophy PJ, Lupski JR (2007) Functional, histopathologic and natural history study of neuropathy associated with EGR2 mutations. Neurogenetics 8:257-262.

Tam SL, Gordon T (2003) Mechanisms controlling axonal sprouting at the neuromuscular junction. J Neurocytol 32:961-974.

Tooth H (1886) The peroneal type of progressive muscular atrophy. London: H. K. Lewis.

Topilko P, Schneider-Maunoury S, Levi G, Baron-Van Evercooren A, Chennoufi AB, Seitanidou T, Babinet C, Charnay P (1994) Krox-20 controls myelination in the peripheral nervous system. Nature 371:796-799.

Ulzheimer JC, Peles E, Levinson SR, Martini R (2004) Altered expression of ion channel isoforms at the node of Ranvier in P0-deficient myelin mutants. Mol Cell Neurosci 25:83-94.

Verhoeven K, De Jonghe P, Van de Putte T, Nelis E, Zwijsen A, Verpoorten N, De Vriendt E, Jacobs A, Van Gerwen V, Francis A, Ceuterick C, Huylebroeck D, Timmerman V (2003) Slowed conduction and thin myelination of peripheral nerves associated with mutant rho guanine-nucleotide exchange factor 10. Am J Hum Genet 73:926-932.

Warner LE, Mancias P, Butler IJ, McDonald CM, Keppen L, Koob KG, Lupski JR (1998) Mutations in the early growth response 2 (EGR2) gene are associated with hereditary myelinopathies. Nat Genet 18:382-384.

Warner LE, Svaren J, Milbrandt J, Lupski JR (1999) Functional consequences of mutations in the early growth response 2 gene (EGR2) correlate with severity of human myelinopathies. Hum Mol Genet 8:1245-1251.

Wrabetz L, Feltri ML, Quattrini A, Imperiale D, Previtali S, D’Antonio M, Martini R, Yin X, Trapp BD, Zhou L, Chiu SY, Messing A (2000) P(0) glycoprotein overexpression causes congenital hypomyelination of peripheral nerves. J Cell Biol 148:1021-1034.

Yin X, Kidd GJ, Pioro EP, McDonough J, Dutta R, Feltri ML, Wrabetz L, Messing A, Wyatt RM, Balice-Gordon RJ, Trapp BD (2004) Dysmyelinated lower motor neurons retract and regenerate dysfunctional synaptic terminals. J Neurosci 24:3890-3898.

Züchner S, Vance JM (2006) Mechanisms of disease: a molecular genetic update on hereditary axonal neuropathies. Nat Clin Pract Neurol 2:4553. 